\title{
ACUTE APPENDICITIS IN ELDERLY PATIENTS- CHALLENGES IN DIAGNOSIS AND MANAGEMENT
}

\author{
Sunilkumar Singh Salam¹, Laitonjam Chinglensana ${ }^{2}$,Vanlalremsiama33, Yumnam Priyabarta4, Manoharmayum Birkumar Sharma ${ }^{5}$
}

${ }_{1}^{1}$ Assistant Professor, Department of General Surgery, Regional Institute of Medical Sciences, Imphal, Manipur, India. ${ }^{2}$ Assistant Professor, Department of General Surgery, Regional Institute of Medical Sciences, Imphal, Manipur, India. ${ }^{3}$ Resident, Department of General Surgery, Regional Institute of Medical Sciences, Imphal, Manipur, India.

${ }^{4}$ Assistant Professor, Department of Radiodiagnosis, Regional Institute of Medical Sciences, Imphal, Manipur, India. ${ }^{5}$ Professor, Department of General Surgery, Regional Institute of Medical Sciences, Imphal, Manipur, India.

\section{BACKGROUND}

ABSTRACT

Acute appendicitis in elderly patients presents with delayed and atypical presentations and it leads to increased frequency of perforation and intra-abdominal infections requiring prompt diagnosis and surgical intervention.

\section{MATERIALS AND METHODS}

The cross-sectional study was conducted on patients with diagnosis of acute appendicitis aged 60 years and above, admitted in the surgical wards of Department of Surgery, RIMS, Imphal. The study was conducted for a period of 2 years from September 2014 to September 2016.

\section{RESULTS}

Majority of the patients were from the age group 60 - 70 years (66.7\%). Males were more than females (55.6\% vs. $44.4 \%)$. More than half of the patients were from urban areas (55.6\%) and majority were from middle class families (88.8\%). All the patients in the study presented with pain abdomen, 10 patients (18.5\%) with typical pain abdomen and 44 patients (81.4\%) with atypical pain abdomen. In 18 cases (33.3\%), there was history of anorexia and 18 cases (33.3\%) gave a history of vomiting with varying frequency. Fever was present in 30 cases (55.6\%). 2 patients (3.7\%) had diarrhoea and 25 (46.2\%) gave history of constipation. Majority of the patients (81.4\%) were diagnosed as acute appendicitis, $11.1 \%$ as appendicular abscess and appendicular perforation in $7.4 \%$ of cases. Appendicectomy was performed in 29 patients (53.7\%), laparotomy was performed in 1 case (1.8\%), where there was generalised peritonitis and incision and drainage done in 6 cases (11.1\%) and non-operative treatment considered in 18 patients $(33.3 \%)$.

\section{CONCLUSION}

Acute appendicitis is a common surgical emergency and is a frequently suspected differential diagnosis presenting with acute abdominal pain. Majority of the patients usually present late, commoner in male sex, lives in urban areas. Most of the patients had atypical presentation with only $18.5 \%$ having typical presentation. Resuscitation plays a key role, while monitoring an elderly patient with acute abdomen before a clinical diagnosis is made. Presence of any co-morbid condition, which is a common finding in elderly increases the morbidity and mortality.

\section{KEY WORDS}

Acute Appendicitis, Appendicular Abscess, Appendicular Perforation, Appendicectomy.

HOW TO CITE THIS ARTICLE: Salam SS, Chinglensana L, Vanlalremsiama, et al. Acute appendicitis in elderly patients- challenges in diagnosis and management. J. Evolution Med. Dent. Sci. 2018;7(32):3585-3589, DOI: 10.14260/jemds/2018/805

\section{BACKGROUND}

Acute appendicitis is the most common acute surgical condition. The lifetime risk of acute appendicitis is $7 \%$ in the general population. ${ }^{1}$ It is a common condition and a frequently suspected differential diagnosis in patients presenting with acute abdominal pain. The incidence of appendicitis seems to have risen greatly in the first half of the twentieth century, particularly in Europe, America and Australia with upto $16 \%^{2}$ of the population undergoing appendicectomy. Acute appendicitis is relatively rare in infants and becomes increasingly common in childhood and

'Financial or Other Competing Interest': None.

Submission 30-06-2018, Peer Review 24-07-2018,

Acceptance 30-07-2018, Published 06-08-2018.

Corresponding Author:

Dr. Laitonjam Chinglensana,

Singjamei Thongam Leikai,

Lane 3, Imphal West-795001,

Manipur, India.

E-mail: chinglensana@rediffmail.com

DOI: $10.14260 /$ jemds $/ 2018 / 805$ early adult life with $90 \%$ of cases occurring in children and young adults $(10-30 \text { years })^{3}$ and upto $10 \%$ in the elderly over 60 years. 4,5 While acute appendicitis is primarily a disease of the younger population with only $5 \%-10 \%$ of cases occurring in elderly person, the incidence of appendicitis in older patients seems to be increasing with an increase in life expectancy. 4,5,6,7,8,9

If the inflamed appendix is not attended to urgently, it will proceed to gangrene and perforation, and result in peritonitis or abscess formation. Morbidity and mortality rates are greater in older patients who often have delayed and atypical presentation leading to increased frequency of perforation and intra-abdominal infections. Moreover, elderly patients have more underlying diseases and sluggish bodily physiologic reactions resulting in higher mortality and morbidity. 4,10 The risk of perforation in the elderly population is reaching levels up to $70 \%$ and morbidity and mortality in the elderly remains significant at $28 \%-60 \%$ and $10 \%$ respectively. ${ }^{6}$ Diagnostic studies may cause further delay in definitive management and associated illness increases operative risks. $4,5,10$ 
The symptoms of appendicitis overlap considerably with other clinical conditions which include gastroenteritis, urinary tract infections and pelvic inflammatory disease. There is no single diagnostic test that can accurately diagnose appendicitis in all cases. Despite technological advances, the diagnosis of appendicitis is still based primarily on the patient's history and physical examination. ${ }^{8}$ When there is a coexisting or underlying medical problem, the symptoms and findings of acute appendicitis may be confused with the already existing symptoms making the clinical diagnosis of appendicitis more difficult. In addition, concurrent medication may further complicate this issue and further compromise the elderly physiology increasing susceptibility to other conditions. Acute appendicitis shows a different pathogenesis, clinical course and outcome in the elderly. The diagnosis of acute appendicitis in elderly patients is thus difficult and may sometimes need serial abdominal examinations and can be one of the most challenging issues in surgery. The elderly patients frequently refuse medical care, which can impede treatment and outcome. Delay in seeking medical attention is a contributing factor in the increase of complication rates. In addition, the patients' failure to recognise the seriousness of their symptoms, greater tolerance of pain and discomfort, reluctance to ask for help aggravate the condition.

The difficulty in distinguishing appendicitis from other common causes of abdominal pain in elderly patients and the high risk of morbidity and mortality accompanying perforation makes appendicitis an important concern for the surgeon to diagnose early. Differentiating appendicitis from other causes of abdominal pain in elderly patients still remains unsatisfactory, and there is no perfect laboratory or radiological investigation for diagnosing appendicitis. The purpose of this study is to have a thorough knowledge about appendicitis in elderly in view of its presentation, clinical and laboratory findings. This study will also help in how any underlying disease can affect its disease process, so that this will lead us gaining in better management of appendicitis in elderly patients. This study will also help in the better management of elderly patients having acute appendicitis with other concomitant medical conditions.

\section{MATERIALS AND METHODS}

The cross-sectional study was conducted on patients with diagnosis of acute appendicitis aged 60 years and above, admitted in the surgical wards of Department of Surgery, RIMS, Imphal, for a period of 2 years from September 2014 to September 2016. Study population was chosen by convenience sampling and 54 cases of elderly patients (60 years or more) with acute appendicitis were admitted during the study period. Approval of the Institutional Ethics Committee, Regional Institute of Medical Sciences, Imphal was obtained and confidentiality was maintained.

Evaluation parameters included pain abdomen (Typical migration of pain to the right iliac fossa or pain starting in right iliac fossa), nausea, vomiting, anorexia, fever (temperature $>99^{\circ} \mathrm{F}$ ), bowel and urinary disturbances, pulse rate, duration of symptoms, presence of co-morbidities, tenderness in right iliac fossa, rebound tenderness, Rovsing's sign, cough tenderness, obturator test, psoas test, abdominal distension, bowel sound, guarding, rigidity, palpable mass, rectal tenderness, White Blood Cell (WBC) count, intra- operative findings, outcome of treatment, length of hospital stay and histopathological examination of appendix.

A detailed history was taken regarding age, sex and duration of the complaints of the patient. Blood samples were collected at the initial encounter and haemoglobin, Total Leucocyte Count (TLC) and kidney function tests were done. Plain abdominal radiograph, chest radiograph and ultrasonography of abdomen were done.

The diagnosis of acute appendicitis was first made clinically, which was aided by ultrasonography of abdomen. After resuscitation and preparation, those patients who were fit for surgery were operated. Operative findings were recorded in detail as to position, gross appearance, gangrene, perforated or abscess, etc. The removed appendix was sent for histopathological examination. Patients with appendicular abscess were drained either by open or with ultrasoundguided aspiration. The observations of the study are recorded in database programme SPSS version 21 for Windows.

\section{RESULTS}

Majority of the patients were from the age group $65-70$ years, which consisted $66.7 \%$ of cases. Mean age was 72 years. Males were more than females (55.6\% vs. $44.4 \%)$ with male-female ratio being 1.25: 1 . More than half of the patients were from urban areas (55.6\%). Most of the patients were from middle class family in $88.8 \%$ of cases. 10 patients (18.5\%) presented with typical pain abdomen and 44 patients $(81.4 \%)$ presented with atypical pain abdomen.

In 18 cases (33.3\%), there was history of anorexia and 18 cases $(33.3 \%)$ gave a history of vomiting with varying frequency. Fever was present in 30 cases (55.6\%). 2 patients $(3.7 \%)$ were associated with diarrhoea and $25(46.2 \%)$ gave history of constipation. More than two-thirds, 47 patients $(87.03 \%)$ had pulse rate above $90 / \mathrm{min}$, out of which 4 patients $(7.4 \%)$ had pulse rate above $120 / \mathrm{min}$. Majority of the patients, 47 patients $(87.03 \%)$ had temperature above $99.1^{\circ} \mathrm{F}$, out of which 3 patients had temperature above $102^{\circ} \mathrm{F}$. Co-morbid conditions were present in 21 patients $(38.9 \%)$ and the most common was hypertension in $16.7 \%$ of cases. Right Iliac Fossa (RIF) tenderness was present in 24 patients (44.4\%) and rebound tenderness in 18 patients (33.3\%). Guarding and rigidity was present in $6(11.1 \%)$ and 6 $(11.1 \%)$ respectively. Palpable mass was present in $22.2 \%$ of cases. TLC was more than 10,100 in 47 patients (87.03\%), out of which 5 patients $(9.2 \%)$ had TLC $>15,000$. Majority of the patients were diagnosed as acute appendicitis (81.4\%), $11.1 \%$ as appendicular abscess and appendicular perforation in $7.4 \%$ of cases. Appendicectomy was performed in 29 patients $(53.7 \%)$ and laparotomy was performed in 1 case $(1.8 \%)$, where there was generalised peritonitis and incision and drainage done in 6 cases $(11.1 \%)$ and non-operative treatment considered in 18 patients $(33.3 \%)$. More than half of the patients' $(16,53.3 \%)$ appendices were retrocaecal and others like post-ileal, paracaecal and pre-ileal were $13.3 \%$, $13.3 \%$ and $10 \%$ respectively. Pelvic location was seen in 2 cases (6.6\%). Among those who were operated, $50 \%$ of cases had uncomplicated appendicitis, $36.6 \%$ of cases had gangrenous appendicitis and $13.3 \%$ of cases had perforated appendicitis. Following surgery, $14.8 \%$ had wound infection and $9.2 \%$ had fever. Among those who were treated conservatively, 3 patients (5.5\%) had pelvic abscess. Majority 
of the patients, 30 stayed for 6 days (55.5\% of cases) and 3 patients $(5.5 \%)$ stayed for $>10$ days.

\begin{tabular}{|c|c|c|}
\hline Age in Years & No. of Patients & Percentage (\%) \\
\hline $60-70$ & 36 & 66.7 \\
\hline $71-80$ & 7 & 13.0 \\
\hline $81-90$ & 7 & 13.0 \\
\hline$>90$ & 4 & 7.4 \\
\hline Total & $\mathbf{5 4}$ & $\mathbf{1 0 0 . 0}$ \\
\hline Mean \pm SD & \multicolumn{2}{|c|}{$72 \pm 9.3$} \\
\hline \multicolumn{2}{|c|}{ Table 1. Age distribution of the Patients }
\end{tabular}

\begin{tabular}{|c|c|c|c|}
\hline \multicolumn{2}{|c|}{$\begin{array}{c}\text { Presenting Complains } \\
\text { (Present) }\end{array}$} & $\begin{array}{c}\text { No. of } \\
\text { Patients }\end{array}$ & $\begin{array}{c}\text { Percentage } \\
\text { (\%) }\end{array}$ \\
\hline \multirow{2}{*}{ Pain abdomen } & Typical & 10 & 18.5 \\
\cline { 2 - 4 } & Atypical & 44 & 81.4 \\
\hline \multicolumn{2}{|c|}{ Fever } & 30 & 55.6 \\
\hline \multicolumn{2}{|c|}{ Nausea } & 36 & 66.7 \\
\hline \multicolumn{2}{|c|}{ Vomiting } & 18 & 33.3 \\
\hline \multicolumn{2}{|c|}{ Loss of appetite } & 18 & 33.3 \\
\hline \multirow{2}{*}{ Bowel habits } & Diarrhoea & 2 & 3.7 \\
\cline { 2 - 4 } & Constipation & 25 & 46.2 \\
\hline \multicolumn{2}{|c|}{ Urinary disturbances } & 0 & 0.0 \\
\hline \multicolumn{3}{|c|}{ Table 2. Distribution of the patients by presenting } \\
Complaints \\
\hline
\end{tabular}

\begin{tabular}{|c|c|c|}
\hline $\begin{array}{c}\text { Examination Findings } \\
\text { (Present) }\end{array}$ & $\begin{array}{c}\text { No. of } \\
\text { Patients }\end{array}$ & $\begin{array}{c}\text { Percentage } \\
(\%)\end{array}$ \\
\hline RIF tenderness & 24 & 44.4 \\
\hline Rebound tenderness & 18 & 33.3 \\
\hline Rovsing's sign & 6 & 11.1 \\
\hline Cough tenderness & 12 & 22.2 \\
\hline $\begin{array}{l}\text { Cope's Psoas and Obturator test } \\
\text { positive }\end{array}$ & 0 & 0.0 \\
\hline Abdominal distension & 6 & 11.1 \\
\hline Bowel sound absent & 6 & 11.1 \\
\hline Guarding and rigidity & 12 & 22.2 \\
\hline Palpable mass & 12 & 22.2 \\
\hline Rectal tenderness & 2 & 5.7 \\
\hline
\end{tabular}

\begin{tabular}{|c|c|c|}
\hline Diagnosis & $\begin{array}{c}\text { No. of } \\
\text { Patients }\end{array}$ & $\begin{array}{c}\text { Percentage } \\
(\%)\end{array}$ \\
\hline Acute appendicitis & 44 & 81.4 \\
\hline Appendicular abscess & 6 & 11.1 \\
\hline Appendicular perforation & 4 & 7.4 \\
\hline Total & 54 & 100.0 \\
\hline
\end{tabular}

\begin{tabular}{|c|c|c|}
\hline HPE Findings & \begin{tabular}{|l|} 
No. of Cases \\
\end{tabular} & \begin{tabular}{|l|} 
Percentage (\%) \\
\end{tabular} \\
\hline Uncomplicated appendicitis & 15 & 50 \\
\hline Gangrenous appendicitis & 11 & 36.6 \\
\hline Perforated appendicitis & 4 & 13.3 \\
\hline No appendicular pathology & 0 & 0.0 \\
\hline Total & 29 & 100.0 \\
\hline
\end{tabular}

\section{DISCUSSION}

The present prospective series consists of 54 patients aged 60 years and above, with a mean age of $72+9.3$ years which was almost consistent with the findings of Wagih Mommtaz Ghnnam,11 in which the mean age was 74.8 years, but in a study by Lunca $S$ et $\mathrm{al}^{12}$ the mean age was found to be 65.1 years, but the male-female ratio of 1.3: 1 is consistent with our findings, whereas in a study by Hartwig Korner et al ${ }^{13}$ the male-female ratio was found to be 1.05: 1 .

In a series by Zbierska $\mathrm{K}$ et al,14 the mean age of patients with appendicitis was $71.6( \pm 7.4)$, whose finding is almost consistent with our study with the mean age of $72 \pm 9.3$ years. In a study by Pooler, BD et al ${ }^{15}$ the mean age was $75.6 \pm 7.5$ years.

VY Kong et al 16 studied a population of 500 appendicitis patients, where more than half were from urban areas. This finding correlates with our study, where $55.6 \%$ were from the urban group.

In the present series, the majority of patients were from the middle-income group (88.8\%). Mann $\mathrm{CV}^{17}$ reported similar findings, whereas Kai-Biao Lin et al ${ }^{18}$ published that the overall incidence of appendicitis was $34.99 \%$ higher in the Low Income Pool (LIP) than in the Normal Population (NP).

The main presenting complaint was pain abdomen and in our study all patients present with pain abdomen, which is a similar finding with Wagih Mommtaz Ghnnam.11 Typical migrating right iliac fossa pain was observed in only $18.5 \%$ in our study, which is comparatively lesser to a study by Zbierska $\mathrm{K}^{14}$ where $46.5 \%$ had right iliac fossa pain and $47 \%$ in Omari AH. ${ }^{19}$

Gary Hals 20 in 2010 pointed out the frequency of atypical and typical pain abdomen. He mentioned that "Classical" presentations of appendicitis are reported in only 50\% - 60\% of patients. While most patients present with abdominal pain, classical history of migration of the pain to the right lower quadrant was absent in $60 \%-80 \%$. Only about two-thirds complain of nausea, vomiting or anorexia.

Pain abdomen is usually accompanied by nausea and vomiting and in our study nausea and vomiting were present in $66.7 \%$ and $33.3 \%$ respectively. Sorinel Lunca et al ${ }^{12}$ observed vomiting in $30.1 \%$, which is consistent with our findings, whereas Lee et al ${ }^{21}$ observed in $25 \%$ and Hui et al ${ }^{22}$ in $20 \%$ and $25 \%$ in Omer Salahuddin et al. ${ }^{23}$ The percentage of nausea as observed by Sorinel Lunca et al,12 Lee et $\mathrm{al}^{21}$ and Hui et $\mathrm{al}^{22}$ were $49.2 \%, 43 \%$ and $48 \%$, which are less compared to our study.

Fever and constipation were observed in about half of the patients (55.6\% and $46.2 \%$ ), which is in co-relation with Sorinel Lunca et al $1249.2 \%$ and $45 \%$.

The elderly patients usually present with prolonged duration of symptoms. In our study, majority of patients presented within 24 hours of the onset of symptoms and only $22.2 \%$ presented after 24 hours with a mean duration of $29 \pm 18.1$ hours. This is comparatively lesser to a study by Zbierska $\mathrm{K}$ et al, ${ }^{14}$ where the mean duration is 47.13 hours, but is consistent to a study by Ghnnam WM, 11 where $87 \%$ of patients presented within 24 hours. Pokharel et al24 and James MW et al25 also noted the mean duration to be 3.05 days and 4.9 days respectively.

In our study by Sorinel Lunca et $\mathrm{al}^{12}$ co-morbidities were present in $60.3 \%$ and $60 \%$ respectively, which is comparatively higher than our study where $38.9 \%$ have comorbidities. Burns PR et $\mathrm{al}^{26}$ had similar findings to our study, where co-morbidities were seen in 38\%. Hypertension was the commonest co-morbidity $(16.7 \%)$, which was similar to the two studies. K Zbierska et al ${ }^{14}$ noticed co-morbidities in $95.7 \%$ of the total elderly patients and Hui et al22 found co- 
morbidities in $75 \%$. Siripong Sirikurnpiboon et $\mathrm{al}^{27}$ had noticed presence of co-morbidities in $60.7 \%$.

Gary Hals et $\mathrm{al}^{20}$ in 2010 noted that right iliac fossa tenderness was noted to be present in $77 \%$ of elderly patients and only two-thirds (33.3\%) have rebound tenderness and the classic psoas and obturator signs are absent in $85 \%$ - $90 \%$ of exams. In our study, right iliac fossa tenderness was seen in $44.4 \%$, which is lesser, but the frequency of rebound tenderness (33.3\%) found in our study is consistent compared to this series. Siripong Sirikurnpiboon et $\mathrm{al}^{27}$ had found rebound tenderness in $84.4 \%$ of the elderly patients with appendicitis. There was no obturator and psoas sign positive in our study series.

In an advanced or complicated appendicitis, peritonitis will develop and there will be guarding and rigidity along with absent bowel sound. In our study, guarding and rigidity was found in $22.2 \%$ and absent bowel sounds in $11.1 \%$. These findings are consistent with James MW et al,25 where there were $28 \%$ of all cases. In a study by Omari $\mathrm{AH}^{19}$ and Siripong Sirikurnpiboon et al $^{27}$ guarding and rigidity was observed in $75 \%$ and $84.4 \%$, which was higher compared to our study series.

In acute appendicitis, leucocytosis is seen in $75 \%-80 \%$ of patients. However, elderly patients can have normal WBC counts in up to $45 \%$ of patients on presentation. In our study series, leucocytosis (TLC $>11,000 /$ cumm) was seen in $86 \%$ of the cases, this finding is higher as compared to study by Sorinel Lunca et al ${ }^{12}$ where leucocytosis was seen in $69.1 \%$. In a series by Omari $\mathrm{AH}$ et $\mathrm{al}^{19}$ leucocytosis was seen in $63 \%$, which is again lower as compared to our current series. Thomas $\mathrm{T}$ Hui et $\mathrm{a}^{22}$ also found that leucocytosis to be present in $72 \%$, which is almost consistent with our findings.

In 1995 Franz MG et al ${ }^{7}$ found that out of 18 elderly patients with acute appendicitis, only 2 were uncomplicated acute appendicitis and 18 were either complicated into perforation or abscess. On the contrary, Mahattanobon S et $\mathrm{al}^{28}$ in 2014 published a study where $72.4 \%$ were uncomplicated appendicitis and $27.6 \%$ were complicated either to perforation or abscess. This finding is consistent with our current series, where $81.4 \%$ were uncomplicated appendicitis and appendicular abscess and perforation found in $11.1 \%$ and $7.4 \%$ respectively.

In 2016 Zbierska et al ${ }^{14}$ also published in their study that $73.9 \%$ of the elderly patients underwent laparoscopic appendicectomy and only $21.7 \%$ underwent open appendicectomy, whereas Paranjape C et al ${ }^{29}$ showed in their study series that $41.37 \%$ had laparoscopic appendicectomy and $58.62 \%$ had open appendicectomy. In our study series, laparoscopic appendicectomy was not performed and 53.7\% had open appendicectomy.

In a study by Omari $\mathrm{AH}, 19$ out of 214 elderly patients, majority i.e. 168 patients had open appendicectomy and 46 patients had laparotomy by lower midline incision. In our present series, only 1 patient $(1.8 \%)$ had midline laparotomy for diffuse peritonitis from perforated appendicitis.

Yamini D et $\mathrm{al}^{30}$ in 1998 showed in their study that patients were treated initially with intravenous antibiotics and CT-guided drainage was used only if the patient failed to improve after 48 to 72 hours. Only 58 percent of the abscesses required percutaneous drainage. In our series, $11.1 \%$ were treated with either incision and drainage or percutaneous drainage.
In our study in more than half of the patients (53.3\%), appendix positions were retrocaecal and others like postileal, paracaecal and pre-ileal in $13.3 \%, 13.3 \%$ and $10 \%$ respectively. Pelvic location was seen in $6.6 \%$.

In 2016, Zbierska et al ${ }^{14}$ published in their study that $34.8 \%$ were gangrenous appendicitis by histopathological examination, which is consistent with our finding where we had $36.6 \%$ gangrenous appendicitis. $26.1 \%$ in their series were confirmed perforated and $39.1 \%$ were simple appendicitis, whereas in our series $13.3 \%$ were perforated and $50 \%$ were simple appendicitis. In a study by Omer $\mathrm{S}^{23}$ in 2012 , they found that $41.6 \%$ were simple appendicitis after confirmed by histopathological examination, $25 \%$ gangrenous and $33.3 \%$ perforated.

There was no negative appendicectomy in our current series, which is a similar finding by Zbierska et al.14 Kirshtein $B$ et al $^{31}$ in 2009 in their study show that there was negative appendicectomy in $4.9 \%$ and Pooler BD $^{15}$ show in their study series that negative appendicectomy was $2.3 \%$.

In our current study post-operative complications were seen in $23 \%$, out of which wound infection was commonest (14.8\%). This finding is consistent with a study by Zbierska et al,14 where the post-operative complications were $17.4 \%$. Sorinel Lunca et al ${ }^{12}$ and Omer $\mathrm{S}$ et $\mathrm{al}^{23}$ had post-operative complications of $34.9 \%$ and $33.4 \%$ respectively in their series.

According to a study series by Pooler BD et al,15 the duration of hospital stay was 5.07 days in majority of patients. In a study by Sorinel Lunca et al ${ }^{12}$ and Zbierska et al,14 the duration of hospital stay for majority of patients was 6 days, which is consistent with our findings where majority of the patients stayed for 6 days. Omer $\mathrm{S}$ et al ${ }^{23}$ showed in their series that perforated appendicitis usually stayed for 7 - 10 days, which is consistent with our findings where perforated appendicitis stayed for $8-12$ days.

\section{CONCLUSION}

Acute appendicitis is a common surgical emergency and is a frequently suspected differential diagnosis presenting with acute abdominal pain. Difficulty in distinguishing appendicitis from other common causes of abdominal pain and high risk of morbidity and mortality accompanying perforation makes appendicitis an important concern for the clinicians. Despite technological advances, careful history taking and physical examination remain the diagnostic cornerstone in evaluating patients with acute appendicitis. Elderly patients usually present late in the clinical course of the disease and also with atypical presentations, thus resulting in higher morbidity and mortality, thereby requiring urgent care. Meticulous serial abdominal examinations should be performed, and detailed medical history taken. Resuscitation plays a key role while monitoring elderly patients with acute abdomen before a clinical diagnosis is made. Presence of any co-morbid condition, which is a common finding in elderly will increase the morbidity and mortality.

\section{REFERENCES}

[1] Fitz RH. Perforating inflammation of the vermiform appendix: with special reference to its early diagnosis and treatment. Trans Assoc Am Physicians 1886;1:107-44. 
[2] Addiss DG, Shaffer N, Fowler BS, et al. The epidemiology of appendicitis and appendectomy in the United States. Am J Epidemiol 1990;132(5):910-25.

[3] Schwartz SI. Appendix. In: Schwartz SI, edr. Principles of surgery. $6^{\text {th }}$ edn. New York: McGraw Hill 1994: p. 1307-18.

[4] Horattas MC, Guyton DP, Wu D. A reappraisal of appendicitis in the elderly. Am J Surg 1990;160(3):291-3.

[5] Peltokallio P, Tykka H. Evolution of the age distribution and mortality of acute appendicitis. Arch Surg 1981;116(2):153-6.

[6] Smithy WB, Wexner SD, Dailey TH. The diagnosis and treatment of acute appendicitis in the aged. Dis Colon Rectum 1986;29(3):170-3.

[7] Franz MG, Norman J, Fabri PJ. Increased morbidity of appendicitis with advancing age. Am J Surg 1995;61(1):40-4.

[8] Flum DR, Morris A, Koepsell T, et al. Has misdiagnosis of appendicitis decreased over time? A populationbased analysis. JAMA 2001;286(14):1748-53.

[9] Tehrani HY, Petros JG, Kumar RR, et al. Markers of severe appendicitis. Am Surg 1999;65(5):453-5.

[10] Lau WY, Fan ST, Yiu TF, et al. Acute appendicitis in the elderly. Surg Gynecol Obstet 1985;161(2):157-60.

[11] Wagih MG. Elderly versus young patients with appendicitis 3 years of experience. Alexandria J Med 2012;48:9-12.

[12] Lunca S, Bouras G, Romedea NS. Acute appendicitis in the elderly patient: diagnostic problems, prognostic factors and outcomes. Romanian J Gastro 2004;13(4):299-303.

[13] Korner H, Sondenaa K, Soreide JA, et al. Incidence of acute non-perforated and perforated appendicitis: age-specific and sex-specific analysis. World J Surg 1997;21(3):313-7.

[14] Zbierska K, Kenig J, Lasek A, et al. Differences in the clinical course of acute appendicitis in the elderly in comparison to younger population. Pol Przegl Chir 2016;88(3):142-6.

[15] Pooler BD, Lawrence EM, Pickhardt PJ. MDCT for suspected appendicitis in the elderly: diagnostic performance and patient outcome. Emerg Radiol 2012;19(1):27-33.

[16] Kong VY, Van der Linde S, Aldous C, et al. Quantifying the disparity in outcome between urban and rural patients with acute appendicitis in South Africa. S Afr Med J 2013;103(10):742-5.

[17] Mann CV. The vermiform appendix. In: Bailey and Love short practice of surgery. $22^{\text {nd }}$ edn. London: ELBS with Chapman and Hall 1995: p. 828-41.
[18] Lin KB, Lai KR, Yang NP, et al. Epidemiology and socioeconomic features of appendicitis in Taiwan: a 12-year population-based study. World J Emerg Surg 2015;10:42.

[19] Omari AH, Khammash MR, Qasaimeh GR, et al. Acute appendicitis in the elderly: risk factors for perforation. World J Emerg Surg 2014;9(1):6.

[20] Hals G. Acute appendicitis: meeting the challenge of diagnosis in the ED. Retrieved from https://www.ahcmedia.com (April 11, 1999).

[21] Lee JFY, Leow CK, Lau WY, et al. Appendicitis in the elderly. Australian and New Zealand J Surg 2000;70(8):593-6.

[22] Hui TT, Major KM, Avital I, et al. Outcome of elderly patients with appendicitis: effect of computed tomography and laparoscopy. Arch Surg 2002;137(9):995-1000.

[23] Salahuddin 0, Malik MAN, Sajid MA, et al. Acute appendicitis in the elderly: Pakistan Ordnance Factories Hospital, Wah Cantt. Experience. J Pak Med Assoc 2012;62(9):946-9.

[24] Pokharel N, Sapkota P, Kc B, et al. Acute appendicitis in elderly patients: a challenge for surgeons. Nepal Med Coll J 2011;13(4):285-8.

[25] Watters JM, Blakslee JM, March RJ, et al. The influence of age on the severity of peritonitis. Can J Surg 1996;39(2):142-6.

[26] Burns RP, Cochran JL, Russell WL, et al. Appendicitis in mature patients. Ann Surg 1985;201(6):695-704.

[27] Sirikurnpiboon S, Amornpornchareon S. Factors associated with perforated appendicitis in elderly patients in a tertiary care hospital. Article ID 847681, Hindawi Publishing Corporation, Surgery Research and Practice 2015;2015: p. 6

[28] Mahattanobon S, Samphao S, Pruekprasert P. Clinical features of complicated acute appendicitis. J Med Assoc Thai 2014;97(8):835-40.

[29] Paranjape C, Dalia S, Pan J, et al. Appendicitis in the elderly: a change in the laparoscopic era. Surg Endosc 2007:21(5):777-81.

[30] Yamini D, Vargas H, Bongard F, et al. Perforated appendicitis: is it truly a surgical urgency? Am Surg 1998;64(10):970-5.

[31] Kirshtein B, Perry ZH, Mizrahi S, et al. Value of laparoscopic appendectomy in the elderly patient. World J Surg 2009;33(5):918-22. 